\title{
EVALUATION OF DIFFERENT PRESERVATIVES FOR WET DIETS OF CATTLE
}

\author{
Maurício Azambuja Freitas Severino , André Madeira Silveira França', Rômulo \\ Zanesco $^{2}$, Marcus André Ferreira Sá ${ }^{3,4}$, Isabel Cristina Ferreira ${ }^{1}$ \\ ${ }^{1}$ Faculdade de Medicina Veterinária - Universidade Federal de Uberlândia, \\ Uberlândia, MG, Brasil \\ ${ }^{2}$ Médico Veterinário autônomo, Socorro, SP, Brasil \\ ${ }^{3}$ Doutorando do Programa de Pós Graduação em Medicina Veterinária - Patologia e \\ Ciências Clínicas da Universidade Federal Rural do Rio de Janeiro (UFRRJ), \\ Seropédica, RJ, Brasil. \\ ${ }^{4}$ Docente do Curso de Medicina Veterinária do Centro Universitário de Barra Mansa \\ (UBM), Barra Mansa, RJ, Brasil. \\ E-mail para correspondência: marcus.ferreira85@hotmail.com.br
}

Recebido em: 08/04/2017 - Aprovado em: 10/06/2017 - Publicado em: 20/06/2017 DOI: 10.18677/EnciBio_2017A51

\begin{abstract}
We tested the effectiveness of different preservatives for wet diets of cattle. We evaluated the growth of lactobacilli, clostridia, enterobacteria, molds, and yeasts in three experiments using: 1$)$ different concentrations of citric acid $(0,1 \%, 2 \%, 3 \%$, and 4\%); 2) different preservatives (Benzoate, Propionate, Myco Curb, Sodium, Protonic Acid and AS4) diluted at 1\%; and 3) preservatives Benzoate, Propionate, Myco Curb®, Sodium Acid, and Propionic Acid. The results were summarized using descriptive statistics. In experiment 1 there was a large amount of lactobacilli both in the control and in the treated groups. In experiment 2, the amount of colonies was higher than expected. In experiment 3, concentration of lactobacilli colonies increased throughout the time. Our results demonstrate that preservatives should be tested using a higher inclusion level for wet diets to reduce the number of colonies. Propionate, propionic acid, and myco-curb were efficient in controlling molds and yeasts from day 7 to 15 .
\end{abstract}

KEYWORDS: Citric Acid, Propionic Acid, Sodium Acid, bovines, nutrition.

\section{AVALIAÇÃO DE DIFERENTES CONSERVANTES PARA DIETAS MOLHADAS DE GADO}

\section{RESUMO}

Testou-se a eficiência de diferentes conservantes em preservar dietas úmidas para bovinos. Avaliou-se o crescimento de lactobacilos, clostrídios, enterobactérias, bolores e leveduras em três experimentos manipulando: 1) diferentes concentrações de Ácido Cítrico (0, 1\%, 2\%, 3\%, e 4\%); 2) diferentes conservantes (Benzoato, Propionato, Myco Curb ${ }^{\circledR}$, Ácido Sórbico, Ácido Propiônico e AS4) diluídos a 1\%; 3) conservantes Benzoato, Propionato, Myco Curb ${ }^{\circledR}$, Ácido Sórbico e Ácido Propiônico. Os resultados foram resumidos usando estatística descritiva. No experimento 1 houve grande quantidade de lactobacilos tanto no controle, quanto nos grupos tratados. No experimento 2, a quantidade de colônias foi acima do esperado. No 
experimento 3, concentração de colônias de lactobacilos aumentou ao longo do tempo. Nossos resultados demonstram que conservantes devem ser testados utilizando maior nível de inclusão para dietas úmidas para reduzir o número de colônias. O propionato, ácido propiônico, e myco-curb foram eficientes no controle de bolores e leveduras do dia sete ao 15.

PALAVRAS-CHAVE: Ácido Cítrico, Ácido Propiônico, Ácido Sórbico, bovinos, nutrição.

\section{INTRODUCTION}

Animal nutrition is the most important factor determining the economic viability of dairy and beef cattle. Agro-industrial by-products usually reduce losses and promote early pasture rotation, which favors crop and livestock production in the same area. The early pasture rotation is also beneficial for the installation of pasture itself, reducing the drying costs. The limiting factors for using industrial by-products are their seasonal availability and differences in the chemical composition of each batch. These differences influence supply rate and require frequent laboratory analysis to provide different formulations to meet nutritional requirements of animals (CHAVES et al., 2014).

Wet diet is a by-product of the storage of seeds and cereal grains when preserved in anaerobic media, shortly after seed maturation. At this phase, seeds have the highest content of starch, proteins, and lipids, which make them retain great amount of humidity (approximately 30\%), because the transference of nutrients from the plant to the seed ceases (NFT ALLIANCE, 2011). Wet feeding provides the animal with a high energy diet and digestible food that can be stored. Thus, wet diets should be used whenever possible, since they reduce costs while maintaining high productivity (GUIMARÃES et al., 2013).

Wet diets are produced by agro-industries and made of co-products from the processing of corn, sugarcane, and citric acid. However, wet diets have also some drawbacks, mainly associated with their storage. For example, the high moisture usually causes qualitative losses associated with open-air exposure. In addition, this co-product is produced in large amounts to reduce costs. Also, its storage does not involve any specific technique and is usually made by covering tall piles with plastic (FRANÇA et al., 2015).

GoldenMill is the commercial name for Wet Corn Gluten Meal (WCGM), a coproduct from the manufacture of syrup and starch. Shortly, the milling begins with the separation of corn kernels, followed by the removal of undesirable material. Then, corn kernels are swelled by soaking in water and sulfur dioxide. Nutrients migrate to aqueous solution in the immersion. When the maceration is complete, the solution is drained to become the WCGM. WCGM is a highly nutritive food, since it has moderate levels of protein (20-25\%), low content of starch (about 20\%) and oil, and high content of digestible fiber (SANTOS et al., 2013).

The glucose syrup is filtrated in rotary filters using diatomaceous earth precoat as filter aid. The filtrate is composed of $90 \%$ silica. This filtrate is used to clarify glucose (GONÇALVES et al., 2014). The chemical composition of the precoat has on average $73 \%$ of humidity, $12.8 \%$ protein, $17.5 \%$ of ether extract, $50.2 \%$ of NDF, $40.8 \%$ of FDA, $0.13 \%$ of lignin, and $41.6 \%$ of mineral matter (WATANABE, 2013). Raffinate is a syrup produced by the sugar fermentation during the citric acid purification. It has on average 39\% humidity, 9.9\% PB, 3.7\% ether extract, and $16.5 \%$ mineral matter (WATANABE, 2013). Mycelium is produced by the fungus 
Aspergillus niger in the sugar fermentation. It has 60 to $65 \%$ of humidity, $7.15 \%$ of PB, $0.04 \%$ of ether extract, $23.09 \%$ of NDF, $31.03 \%$ of FDA, $0.13 \%$ of lignin, and $0.14 \%$ of mineral matter (WATANABE, 2013).

Chemical preservatives prevent or delay the effects of microorganisms on wet diets while maintaining food quality. The effectiveness of a preservative is influenced by other substances that inhibit the growth of microorganisms (e.g., salt, vinegar, and sugar), $\mathrm{pH}$, product composition, water content of the food, and the initial level of contamination of the food or environment. Chemical preservatives are mainly used in wet and warm regions, where the deterioration of food is higher. Preservatives are also necessary when storage facilities are precarious or when transport is deficient by long distances between production and consumption centers (ALIMENTOS \& INGREDIENTES, 2013).

Several substances can be used as food preservatives, such as citric acid, propionate, sorbate, propionic acid, and benzoic acid (ANVISA, 2011). The choice of preservative should consider the types of microorganisms to be inhibited, handling safety, impact on human or animal consumption, cost, and effectiveness (FOOD INGREDIENTS, 2013). Laboratory tests can help inform the best preservative and its concentration that suppress microorganism growth. Here, we tested the efficiency of different preservatives and their concentrations in inhibiting microorganism growth of wet diets for cattle.

\section{MATERIAL AND METHODS}

Microbiological analyzes were performed at the Laboratory of Quality Control and Food Safety, School of Veterinary Medicine, Federal University of Uberlândia, Minas Gerais, Brazil. We placed $3 \mathrm{Kg}$ of each sample of wet diet (Table 1 ) in buckets at $25{ }^{\circ} \mathrm{C}$ covered with polyethylene lids.

TABLE 1. Percentage and raw weight of each material composing wet diets analyzed.

\begin{tabular}{lcc} 
& Material $(\%)$ & Raw weight $(\mathrm{Kg})$ \\
\hline Sugar cane bagasse & 6.69 & 0.201 \\
GoldenMill $^{\circledR}$ & 42.35 & 1.271 \\
Mycelium $^{\text {Pre-coat }}$ & 11.55 & 0.347 \\
Raffinate & 3.45 & 0.104 \\
Broken corn & 9.96 & 0.299 \\
Nucleus & 24.86 & 0.746 \\
Total & 1.14 & 0.034 \\
\hline
\end{tabular}

We assessed the growth of lactobacilli, clostridia, enterobacteria, molds, and yeasts. We first diluted $25 \mathrm{~g}$ of each sample into $225 \mathrm{~mL}$ of sterile saline solution for sowing in specific culture media for each microorganism. Plates containing Lactobacilli MRS Dehydrated Agar (Difco ${ }^{\mathrm{TM}}$ ) culture medium for lactobacilli were incubated at $35^{\circ} \mathrm{C}$ for three days. For yeasts and molds, we used Potato Dextrose Agar (PDA) culture medium, incubated between 25 and $30^{\circ} \mathrm{C}$ for 3 to 5 days. We differentiated yeasts from molds by the physical structure of colonies. Molds form filamentous multicellular colonies, whereas yeasts are unicellular. For sulphitereducing clostridia, we used the SPS Agar (Difco ${ }^{\mathrm{TM}}$ ) as culture medium. We performed serial dilutions and incubated the plates in anaerobic conditions at $46{ }^{\circ} \mathrm{C}$ 
for 24 to $48 \mathrm{~h}$ (ANVISA, 2001). Enterobacteria were cultured in MacConckey Agar medium.

We conducted three experiments to assess the growth rate of microorganisms. In the first experiment, we used different concentrations of citric acid $(0 \%, 1 \%, 2 \%, 3 \%$, and $4 \%)$. We counted Colony Forming Units (CFU) on the first, fourth, and eighth day of incubation. We tested the dilutions: $10^{-4}, 10^{-5}, 10^{-6}, 10^{-7}$, and $10^{-8}$. In the second experiment, we used different preservatives at $1 \%$ concentration: Benzoate, Propionate, Myco Curb, Sodium, Protonic Acid, and AS4, plus a control (without preservative). We counted CFUs at the start of incubation and 15 days after. The dilutions on day one were $10^{-5}, 10^{-6}, 10^{-7}$, and $10^{-8}$. For day 15 , we used dilutions $10^{-1}, 10^{-2}, 10^{-3}$, and $10^{-4}$. In the third experiment, we used Benzoate, Propionate, Myco Curb®, Sodium Acid, and Propionic Acid, plus a control (without preservative). We counted CFUs on day one, seven, and 15 after the start of the incubation. Dilutions for day one were $10^{-5}, 10^{-6}, 10^{-7}$, and $10^{-8}$; and $10^{-1}, 10^{-2}, 10^{-3}$, and $10^{-4}$ for day 7 and 15. Results were summarized using descriptive statistics for the duration of the experiments. Data on CFUs are presented in log scale.

\section{RESULTS AND DISCUSSION}

\section{Experiment 1}

We found a large amount of lactobacilli in both the control and samples treated with citric acid (Table 2). Lactobacilli rapidly decreased the $\mathrm{pH}$ of the stored material. The CFU/g of silage between 6 and 10 rapidly reduced $\mathrm{pH}$, allowing the conservation of silage in an acidic environment due to the production of lactic acid (JOBIM et al., 1997). Here, the CFU/g of lactobacilli was within the range reported by JOBIM et al. (1997), except for citric acid at $4 \%$. High values of lactobacilli are desirable because they favor silage conservation.

TABLE 2. Lactobacillus count on samples of wet diets treated with citric acid at $1 \%, 2 \%, 3 \%$, and $4 \%$, plus control $(0 \%)$ on days one, four, and eight.

\begin{tabular}{c|c|c|c}
\hline \multirow{2}{*}{} & \multicolumn{3}{|c}{ Storage Days } \\
\cline { 2 - 4 } & \multicolumn{3}{|c}{$\mathbf{4}$} \\
\hline $0 \%$ & 8.22 & UFC/g \\
$1 \%$ & 8.55 & 8.09 & $\mathbf{8}$ \\
$2 \%$ & - & 8.25 & 9.04 \\
$3 \%$ & NA & 8.67 & 8.93 \\
$4 \%$ & 1.65 & 8.60 & 8.70 \\
& 8.31 & 8.06 \\
\hline
\end{tabular}

-: non countable; NA: missing value

Clostridia growth decreased $10 \%$ in the first day of incubation (Table 3 ) in groups treated with up to $3 \%$ citric acid. Conversely, clostridia colonies increased in groups treated with $3 \%$ and $4 \%$ of citric acid on day four. On day eight, colony count reduced by $12.5 \%$ with the increase in citric acid concentration (Table 3 ). Even though the clostridia growth was halted with $4 \%$ citric acid on day eight, demonstrating an improve compared to previous days, it did not show the desired effect. The clostridia count found here are well above those reported by COAN et al (2007) between 1 to $3 \mathrm{CFU/g}$. 
TABLE 3. Clostridia count $(\mathrm{CFU} / \mathrm{g})$ on wet diet samples treated with citric acid at $1 \%, 2 \%$, $3 \%$, and $4 \%$, plus a control on first, forth, and eighth day of incubation.

\begin{tabular}{c|c|c|c}
\hline \multirow{2}{*}{} & \multicolumn{3}{|c}{ Incubation time } \\
\cline { 2 - 4 } $0 \%$ & $\mathbf{3}$ & $\mathbf{4}$ \\
\cline { 2 - 4 } $1 \%$ & 8.23 & UFC/g \\
$2 \%$ & 9.20 & 8.27 & 8.33 \\
$3 \%$ & 8.20 & 8.47 & 8.75 \\
$4 \%$ & 7.38 & 8.38 & 8.91 \\
& 7.49 & 8.49 & 8.42 \\
\hline
\end{tabular}

Citric acid reduced the growth of enterobacteria at $4 \%$ concentration in the first and eighth day of incubation, but their count is still high (Table 4). Low concentrations of citric acid may have stimulated enterobacteria growth, which is undesirable. This pattern was found for clostridia treated with formaldehyde (LALA et al., 2010). The colony counts for enterobacteria we found (Table 4) are above those reported by Jobim et al. (1997, 1999), who found a variation of 1 to $6 \mathrm{CFU} / \mathrm{g}$ in wet corn silage, and ZAMBOM et al. (2014), whose highest value found was $6.17 \mathrm{CFU} / \mathrm{g}$ in silage. Citric acid at $4 \%$ heavily reduced colonies count on day eight. However, the values are still higher than the desired ones.

TABLE 4. Enterobacteria count (CFU/g) on wet diet samples treated with citric acid at $1 \%$, $2 \%, 3 \%$, and $4 \%$, plus a control on first, forth, and eighth day of incubation.

\begin{tabular}{c|c|c|c}
\hline \multirow{2}{*}{} & \multicolumn{3}{|c}{ Incubation time } \\
\cline { 2 - 4 } & \multicolumn{3}{|c}{$\mathbf{4}$} \\
\hline & \multicolumn{3}{|c}{ UFC/g } \\
\cline { 2 - 4 } $1 \%$ & 4 & 7.07 & $\mathbf{8}$ \\
$2 \%$ & 6.81 & 7.96 & 9.19 \\
$3 \%$ & 7.73 & 8.87 & 8.41 \\
$4 \%$ & 7.73 & 8.13 & 7.87 \\
& 7.03 & 8.28 & 7.83 \\
\hline
\end{tabular}

On day one, citric acid increased the counts of mold and yeast colonies from 6 to $8 \%$ compared to the control. On day four, the control had $8.32 \mathrm{CFU} / \mathrm{g}$, but reduced by $4.4 \%$ in $2 \%$ citric acid. However, the counts of molds and yeasts increased $4 \%$ with $4 \%$ citric acid. At day eight, $4 \%$ of citric acid decrease $41.8 \%$ colony counts, ranging from 4.51 to $7.13 \mathrm{CFU} / \mathrm{g}$ (Table 5).

TABLE 5. Count of molds and yeasts (CFU/g) on wet diet samples treated with citric acid at $1 \%, 2 \%, 3 \%$, and $4 \%$, plus a control on first, forth, and eighth day of incubation.

\begin{tabular}{c|c|c|c}
\hline \multirow{2}{*}{} & \multicolumn{3}{|c}{ Incubation time } \\
\cline { 2 - 4 } $0 \%$ & $\mathbf{3}$ & \multicolumn{3}{|c}{$\mathbf{4}$} \\
\cline { 2 - 4 } $1 \%$ & 7.81 & UFC/g & $\mathbf{8}$ \\
$2 \%$ & 8.41 & 8.32 & 8.13 \\
$3 \%$ & 8.15 & 7.95 & 8.04 \\
$4 \%$ & 8.30 & 8.13 & 8.32 \\
\hline
\end{tabular}

JOBIM et al. $(1997,1999)$ found 7 to 13 CFU/g of mold and yeast. Our results were within that range, except for day eight with $4 \%$ citric acid. The $4 \%$ concentration 
on day 8 decreased colony count compared to the control and other concentrations. However, colony count remained high in the remaining incubation times, suggesting that higher nitric acid concentrations should be used.

\section{Experiment 2}

On day one, there was a large number of colonies of lactobacilli, clostridia, enterobacteria, and molds in the control, making the counting on day 15 unnecessary (Table 6).

TABLE 6. Counts of lactobacilli, clostridia, enterobacteria, and molds (CFU/mL) at different dilutions on days one and fifteen of incubation.

\begin{tabular}{|c|c|c|c|c|c|c|c|c|}
\hline & \multicolumn{2}{|c|}{ Lactobacilli } & \multicolumn{2}{|c|}{ Clostridia } & \multicolumn{3}{|c|}{ Enterobacteria } & Molds \\
\hline & \multicolumn{8}{|c|}{ UFC/g } \\
\hline & 1 & 15 & 1 & 15 & 1 & 15 & 1 & 15 \\
\hline Control & 7.84 & *夫 & 7.50 & ** & 7.61 & ** & 8.23 & $\star \star$ \\
\hline Propionic acid & 0 & 7.13 & 0 & 7.69 & 0 & 7.59 & 0 & 9 \\
\hline Sorbic acid & 0 & 7.98 & 0 & 7.61 & 0 & 7.69 & 0 & 0 \\
\hline Benzoate & 0 & 7.03 & 0 & 7 & 0 & 7.41 & 0 & 0 \\
\hline Myco Curb® & 0 & 10.28 & 0 & 8.19 & 0 & 9.46 & 0 & 0 \\
\hline Propionate & 6.46 & 6.02 & 0 & 5.36 & 0 & 8.73 & 0 & 6.02 \\
\hline SA4 & 0 & 10.33 & 0 & 9.21 & 0 & 9.43 & 0 & 0 \\
\hline
\end{tabular}

${ }^{\star *}$ did not included in assay

On day one, colony count was close to 0 in almost all samples, except for Propionate, which had $6.46 \mathrm{CFU} / \mathrm{g}$ of lactobacilli. At day 15, there were lactobacilli, clostridia, and enterobacteria even with the addition of preservatives. Mold occurred only in samples with propionic acid and propionate (Table 6). The amount of microorganisms we found on the 15th day was higher than those reported by JOBIM et al. (1997, 1999) (maximum 6 CFU/g), suggesting that these preservatives were ineffective to halt the growth of clostridia and enterobacteria. Preservative were not effective to preserve samples up to 15 days, since colony count was higher than expected. Therefore, higher concentrations of these preservatives should be tested.

\section{Experiment 3}

The group treated with Myco-Curb had 4.27 CFU/g at day zero, $4 \mathrm{CFU/g}$ day seven, and $4.14 \mathrm{CFU} / \mathrm{g}$ on day 15 , showing a decrease in 4.6 and $3 \%$, respectively (figure 1).JOBIM et al. (1997) found that lactobacilli varied from 6 to $10 \mathrm{CFU} / \mathrm{g}$ of silage and rapid decreased $\mathrm{pH}$. JOBIM et al. (1999) found 8.3 to $8.9 \mathrm{CFU} / \mathrm{g}$ in silages of corn cobs and kernels, respectively. COAN et al. (2007) found none lactobacillus colonies on day zero, $6 \mathrm{CFU} / \mathrm{g}$ on day four, and $11 \mathrm{CFU} / \mathrm{g}$ on day seven in Tanzania grass silages (COAN et al, 2007). Here, propionic acid and myco-curb rapidly decreased $\mathrm{pH}$ at day zero. However, we did not obtain counts above $4.5 \mathrm{CFU} / \mathrm{g}$ for other preservatives.

Clostridial concentration of the control on days zero and seven was 4.99 $\mathrm{CFU} / \mathrm{g}$, and $4.89 \mathrm{CFU} / \mathrm{g}$ on day 15. For propionate, it was $3.92 \mathrm{CFU} / \mathrm{g}$ on day zero, 4.61 CFU/g on day seven, and $4.32 \mathrm{CFU} / \mathrm{g}$ on day 15 . For propionic acid, it was 4.34 $\mathrm{CFU} / \mathrm{g}$ at day zero, 3.94 CFU/g on day seven, and $4.11 \mathrm{CFU} / \mathrm{g}$ on day 15 . For MycoCurb, counts were $4.79 \mathrm{CFU} / \mathrm{g}$ at day zero, $4.2 \mathrm{CFU} / \mathrm{g}$ day seven, and $4.38 \mathrm{CFU} / \mathrm{g}$ on day 15. A previous study (Coan et al., 2007) found less than $1 \mathrm{CFU} / \mathrm{g}$ of clostridia 
on day zero, $1 \mathrm{CFU} / \mathrm{g}$ on day four, and about $3 \mathrm{UFC} / \mathrm{g}$ on day seven in Tanzania grass silage. These values are smaller than the ones found here (see Figure 1).

The control had $5.04 \mathrm{CFU} / \mathrm{g}$ of enterobacteria at day zero, $6.52 \mathrm{CFU} / \mathrm{g}$ on day seven, and $6.52 \mathrm{CFU} / \mathrm{g}$ on day 15 . For the propionate, it was $4 \mathrm{CFU} / \mathrm{g}$ on day zero, 4.04 CFU/g on day seven, and $4.07 \mathrm{CFU} / \mathrm{g}$ on day 15. Samples treated with propionic acid had $4.44 \mathrm{CFU} / \mathrm{g}$ at day zero, $4.04 \mathrm{CFU} / \mathrm{g}$ on day seven, and 3.83 $\mathrm{CFU} / \mathrm{g}$ on day 15 . For those treated with myco-curb, the count was $4.62 \mathrm{CFU} / \mathrm{g}$ at day zero, 4.14 CFU/g day seven, and 3.85 CFU/g on day 15. JOBIM et al. (1997, 1999) found 1 to $3.5 \mathrm{CFU} / \mathrm{g}$ of enterobacteria on wet corn grains. Conversely, COAN et al. (2007), found about 4.3 CFU/g of enterobacteria at day zero in Tanzania grass silage, but colony count was 0 on days four and seven. The preservatives tested here were efficient after day seven, when compared to the control, but colony count was higher than those found in previous studies.

The control had $5.80 \mathrm{CFU} / \mathrm{g}$ of molds and yeasts at day zero, $6.51 \mathrm{CFU} / \mathrm{g}$ on day seven, and $6.52 \mathrm{CFU} / \mathrm{g}$ on day 15 . For propionate, colony count was $4 \mathrm{CFU} / \mathrm{g}$ on day zero, $2.23 \mathrm{CFU} / \mathrm{g}$ on day seven, and $3.39 \mathrm{CFU} / \mathrm{g}$ on day 15. Propionic acid had $4.49 \mathrm{CFU} / \mathrm{g}$ on day zero, $1.77 \mathrm{CFU} / \mathrm{g}$ on day seven, and $1.0 \mathrm{CFU} / \mathrm{g}$ on day 15 . For Myco-Curb, count was 4.73 CFU/g at day zero, $2.32 \mathrm{CFU} / \mathrm{g}$ day seven, and 2.41 $\mathrm{CFU} / \mathrm{g}$ on day 15. Yeasts in wet corn kernel and corn cod silages varied between 6.4 and 8.6 CFU/g, while counts for fungi varied from 0.6 to $3.8 \mathrm{CFU} / \mathrm{g}$ (JOBIM et al., 1997). Therefore, the preservatives tested were efficient between day seven and 15 when compared to the control (see Figure 1).

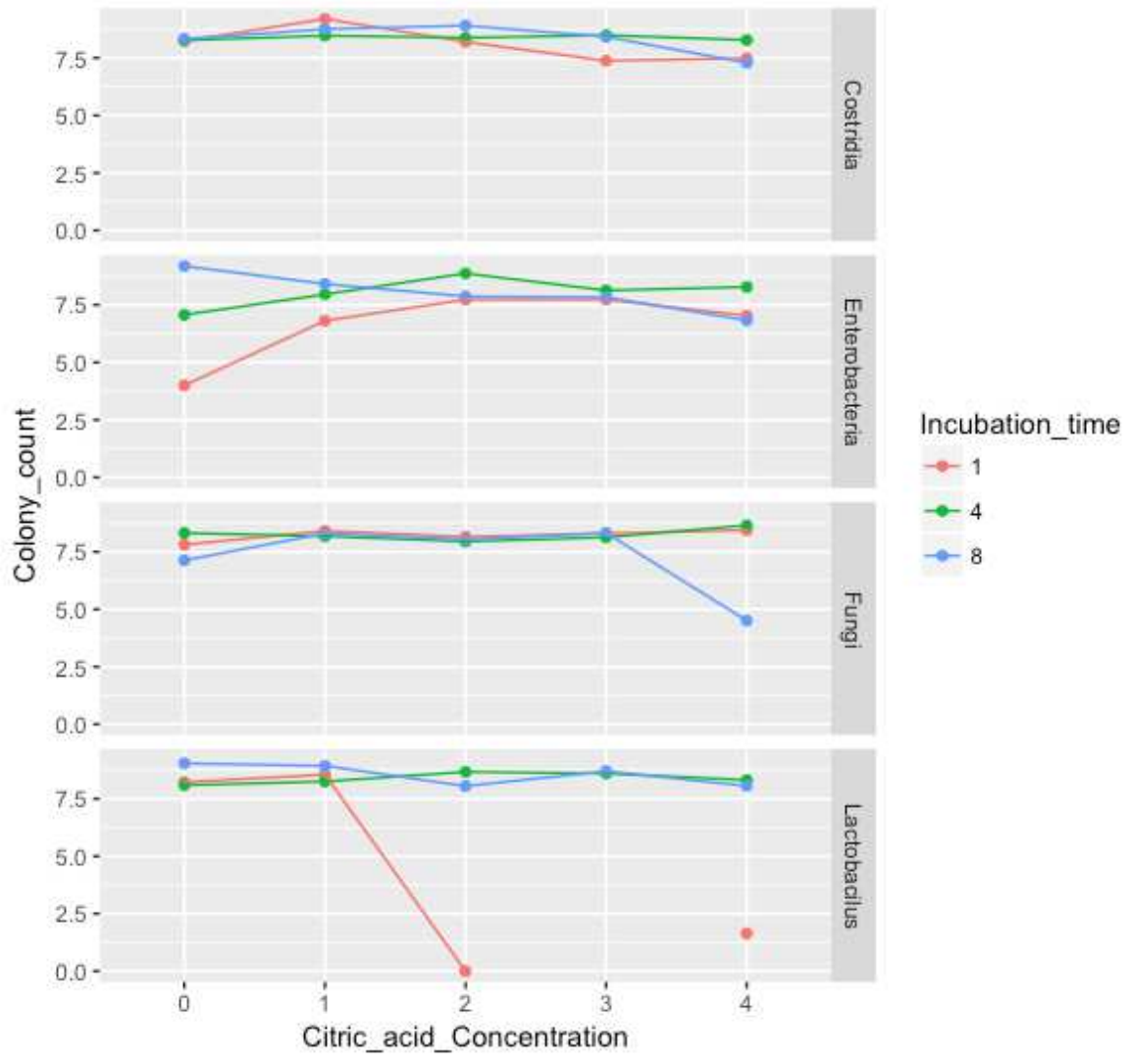

FIGURE 1 Count (CFU/g) of clostridia, enterobacteria, fungi and lactobacilus in wet diets for cattle using different preservatives and incubation times. 


\section{CONCLUSION}

Propriontin, propionic acid, and myco-curb were effective to control molds and yeasts from day 7 to day 15 . However, future studies should test the efficiency of higher concentrations of preservatives in reducing colony counts of wet diets.

\section{REFERENCES}

AGÊNCIA NACIONAL DE VIGILÂNCIA SANITÁRIA. Compêndio da legislação brasileira de aditivos alimentares. Brasília, 163 p., 2011.

CHAVES, B.W. Utilização de resíduos industriais na dieta de bovinos leiteiros. Revista Eletrônica em Gestão, Educação e Tecnologia Ambiental, v. 18, p. 150-156, 2014.

COAN, R.M.; REIS, R. A.; GARCIA, G. R.; SCHOCKEN- ITURRINO, R. P.; FERREIRA, D. S.; RESENDE, F. D.; GURGEL, F. A. Dinâmica fermentativa e microbiológica de silagens dos capins tanzânia e marandu acrescidas de polpa cítrica peletizada. Revista Brasileira de Zootecnia, v.36, n.5, p.1502-1511, 2007.

FRANÇA, A. M. S.; FERREIRA, I. C.; DA COSTA HERMISDORFF, Í.; MENDONÇA, E. P.; DE ABREU FERNANDES, E.; ROSSI, D. A. Dinâmica química, microbiológica e física da silagem de farelo úmido de glúten de milho. Ciência Rural, v. 45, n.4, p. 684-689, 2015.

GONÇALVES, M. F.; OLIVEIRA, M. V.; NOGUEIRA, H. C. R.; SANTOS, A. P. S.; FRANÇA, A. M. S.; DA COSTA HERMISDORFF, I.; DOS SANTOS, R. M. Desempenho de novilhas alimentadas com co-produtos da indústria do milho ou do ácido cítrico. Veterinária Notícias, v.20, n.1, p. 28-36, 2014.

GUIMARÃES, T. P.; MOREIRA, K. K. G.; FERNANDES, S.; FERREIRA, B. J. M. L.; DE SOUZA, F. M.; LINO, F. A. Produção e utilização de silagens de grãos úmidos. PUBVET, Publicações em Medicina Veterinária e Zootecnia. v. 7, n. 1, 2013.

JOBIM, C.C.; REIS, R.A. ; RODRIGUES, L. R. A.; SCHOCKEN-ITURRINO, R. P. Presença de microrganismos na silagem de grãos úmidos de milho ensilado com diferentes proporções de sabugo. Pesquisa Agropecuária Brasileira, v. 32, n. 2, p.201-204. 1997.

JOBIM, C.C.; REIS, R.A. ; RODRIGUES, L. R. A.; SCHOCKEN-ITURRINO, R. P.; ROSA, B. Desenvolvimento de microrganismos durante a utilização de silagens de grãos úmidos de milho e de espigas de milho sem brácteas. Acta Scientiarum, v. 21, n. 3, p. 671-676, 1999.

NFT ALLIANCE. Silagem de grão úmido de milho, 2011.

LALA, B.; PEREIRA, V.V.; POSSAMAI, A.P.S.; DINIZ, P.P.; SILVA, S.C.C.; GRANDE, P.A. Aditivos no processo de ensilagem. Revista Brasileira de Engenharia de Biossistemas, v.4, n.3, p. 175-183, 2010.

SANTOS, S. F.; GONÇALVES, M. F.; RIOS, M. P.; SOUSA, J. T. L.; DE OLIVEIRA, 
M. V.; MIRANDA, M. M.; TAKASSUGUI, C. G.; FERNANDES, E. A. FERREIRA, I. C. Caracterização das silagens de milho com diferentes níveis de inclusão de farelo úmido de glúten de milho. Veterinária Notícias, v.18, n.2, 2013.

ZAMBOM, M.; FERNANDES, T.; SOARES, M. S. S. P.; CASTAGNARA, D. D.; NERES, M.; JAVORSKI, C. E CRUZ, E. A. Características da silagem de resíduo úmido de fécula de mandioca adicionada de níveis de ureia. Archivos de zootecnia, v.63, n. 244, p. 677-688, 2014.

WATANABE, Milena. Comunicação pessoal. 2013. 